\title{
PERANAN SUPERVISI DALAM MENINGKATKAN MUTU PENDIDIKAN \\ NASIONAL
}

Oleh

Ihsan Basari (17329069)

Email: $\underline{\text { Ihsanbasari0203@gmail.com }}$

\begin{abstract}
Abstrak
Kualitas proses belajar mengajar sangat dipengaruhi oleh kualitas kinerja guru. Untuk meningkatkan kemampuan dalam melaksanakan proses pembelajaran, diperlukan perhatian dari penanggung jawab sistem pendidikan secara terus menerus. Kegiatan supervisi dilaksankan melalui berbagai proses pemecahan masalah pengajaran dan bertujuan untuk meningkatkan efektivitas dan efisiensi proses belajar-mengajar. Supervisi merupakan bantuan kepada guru dalam perbaikan situasi belajar-mengajar, supervisi pendidikan meliputi supervisi terhadap pengajaran maupun komponen pendukungnya. Supervisi pengajaran merupakan kegiatan yang berhubungan langsung dengan pengajaran tetapi tidak langsung dengan siswa. Supervisi dapat dilakukan dengan teknik seperti kunjungan kelas, wawancara, atau juga bisa melakukan ujian mendadak. Kepala sekolah sebagai supervisor dituntut mengawasi, mengevaluasi dan membimbing seluruh sumber daya Sekolah menggunakan prinsip TEAM WORK yang mengandung pengertian adanya rasa kebersamaan (Together), pandai merasakan (Empathy), saling membantu (Asist), saling penuh kedewasaan (Maturity), saling mematuhi (Willingness), saling teratur (Organization), saling menghormati (Respect), dan saling berbaik hati (Kindness). Keputusan Menteri Pendidikan Nasional (Mendiknas) Nomor 162 Tahun 2003 tentang Pedoman Penugasan Guru sebagai Kepala Madrasah disebutkan bahwa tugas kepala Madrasah sebagai educator, manager, administrator, supervisor, leader, entrepreneur dan cilmate creator.
\end{abstract}

Kata Kunci : kualitas kinerja guru, peranan supervisor, kualitas pendidikan 


\section{PENDAHULUAN}

\section{A. Latar Belakang}

Keberhasilan pembaharuan sekolah sangat ditentukan oleh gurunya, karena guru adalah pemimpin pembelajaran, fasilitator, dan sekaligus merupakan pusat inisiatif pembelajaran (Mulyasa: 1995:9). Aktifitas guru sebagai tenaga pengajar menjadi landasan dalam pencapaian tujuan pendidikan dalam sekolah, kegiatan yang dilakukan guru sangat berpengaruh terhadap pelaksanaan proses pembelajaran, hal ini dikarenakan seorang guru dalam berbagai kegiatannya menjadi seorang pemimpin serta pembimbing dalam kelas. Guru adalah pendidik profesional dengan tugas utama mendidik, mengajar, membimbing, mengarahkan, melatih, menilai, dan mengevaluasi peserta didik pada pendidikan anak usia dini jalur pendidikan formal, pendidikan dasar, dan pendidikan menengah (Undang-undang No. 142005 tentang Guru dan Dosen). Tujuan pendidikan dan tujuan belajar meliputi tiga aspek, yaitu: Aspek kognitif, aspek afektif dan aspek psikomotorik (piet sahertian: 2000: 19).

\section{B. Rumusan Masalah}

1. Apa saja permasalahan (problem) yang terjadi dalam pelaksanaan supervisi pendidikan di sekolah?

2. Bagaimana cara atau alternative pemecahan permasalahan dalam pelaksanaan supervise di sekolah?

\section{Tujuan penulisan}

1. Menambah pengetahuan tentang permasalahan yang terjadi dan cara menyelesaikan permasalahan pelaksanaan supervisi pendidikan disekolah.

2. Dapat menjelaskan secara sederhana bagaimana cara menyelesaikan permasalahan pelaksanaan supervisi pendidikan. 


\section{PEMBAHASAN}

\section{a. Supervisi Pendidikan}

Perkembangan supervisi pendidikan berkembang seiring dengan perkembangan ilmu pengetahuan, teknologi, serta sosial ekonomi dan budaya masyarakat. Supervisi bergerak dari berbentuk inspeksi dimana otoritas lebih didominasi oleh supervisor, berkembang dalam bentuk kolaborasi antara supervisor dan guru bersama berinisiatif dan bertanggungjawab dalam meningkatkan kualitas pembelajaran, serta menumbuhkan budaya belajar pada guru untuk selalu meningkatkan kompetensinya. (Sabandi, 2013)

\section{b. Kegiatan supervisi}

Kegiatan supervisi bermaksud untuk menjaga dan memelihara kualitas

seorang guru, dalam proses pembelajaran di sekolah, kegiatan supervise sangat penting bila menginginkan kualitas pendidikan yang baik di sekolah, hal ini disebabkan karena supervisi merupakan bantuan terhadap guru. (Maralih, 2014) mengemukakan tujuan supervisi adalah memberikan layanan dan bantuan untuk meningkatkan kualitas mengajar guru di kelas yang pada gilirannya untuk meningkatkan kualitas mengajar guru di kelas yang pada giliranya untuk meningkatkan kualitas belajar siswa.

\section{c. Upaya Dalam Meningkatkan Supervisi}

Kepala sekolah diharapkan dapat menyusun suatu program supervisi yang mampu memberikan bantuan kepada guru-guru agar mereka memperbaiki dirinya sendiri secara maksimal dan memfasilitasi apa saja yang menjadi kebutuhan guru. Supervisi pada hakekatnya melakukan pengawasan terhadap proses pendidikan di sekolah, kegiatan supervisi masuk ke dalam jalinan interaksi kepala sekolah dengan guru didalam kegiatan belajar mengajar. Peningkatan kualitas diri guru dapat dilakukan melalui layanan supervisi pengajaran kepala sekolah. Layanan supervisi itu bertujuan untuk meningkatkan profesionalisme, dalam proses pembelajaran, Peningkatan kinerja dan profesionalisme guru sangat diperlukan, karena peningkatan kinerja dan profesionalisme guru (Maralih, 2014). Apabila guru telah memiliki propesionalitas yang baik maka tujuan pembelajaran akan mudah dicapai. 


\section{PENUTUP}

\section{Kesimpulan}

Berdasarkan pembahasan di atas Dalam meningkatkan kemampuan guru dalam melaksanakan proses belajar mengajar, memerlukan perhatian dari penanggung jawab sistem pendidikan secara terus menerus agar tujuan dari pendidikan tersebut dapat tercapai dengan maksimal, Dalam pelaksanaannya supervisi dapat dilakukan melalui pendekatanpendekatan yang harus dilakukan supervisor kepada guru, supervisi pengajaran merupakan pekerjaan professional, yang menuntut persyaratan sebagaimana layaknya pekerjaan professional yang lain. Tugas seorang supervisor bukanlah untuk mengadili tetapi untuk membantu, mendorong, dan memberikan keyakinan kepada guru bahwa proses belajar mengajar dapat dan harus diperbaiki.

\section{Saran}

Agar pendidikan di Indonesia memiliki kualitas yang tinggi maka seorang supervisor harus melaksanakan tugasnya dengan baik, dan guru juga melakukan apa yang disarankan supervisor, agar pendidikan nasional dapat berkualitas.

\section{DAFTAR PUSTAKA}

Maralih. (2014). Peranan Supervisi Dalam Peningkatan Kualitas Pendidikan. Jurnal Qathrunâ Vol. $\quad 1 \quad$ No.1, 1(1), 179-192. $\quad$ Retrieved from http://jurnal.uinbanten.ac.id/index.php/qathruna/article/view/251

Sabandi, A. (2013). Supervisi Pendidikan Untuk Pengembangan Profesionalitas Guru Berkelanjutan. Jurnal Ilmiah Ilmu Pendidikan, XIII(2), 1-9. Retrieved from http://ejournal.unp.ac.id/index.php/pedagogi/article/view/4275

Mulyasa. (2003). Kurikulum Berbasis Kompetensi, Konsep, Karakteristik dan Implementasi.Bandung: Remaja Rosdakarya. 
Piet. A Sahertian (2000). Konsep Dasar danTteknik Supervisi Pendidikan dalam Rangka Pengembangan Sumber Daya Manusia. Jakarta: Rineka Cipta. 